\title{
Järjestömuotoista vertaisoppimista vapaassa sivistystyössä - tapaus opintokerhot
}

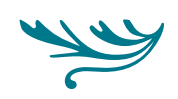

\begin{abstract}
Vertaisoppiminen voidaan määritellä keskenään tasa-arvoisessa suhteessa olevien henkilöiden välisessä vuorovaikutuksessa tapahtuvaksi oppimiseksi. Se on aidosti sosiaalinen oppimisen muoto, koska oppijalla

tulee aina olla kumppani, vertainen, jota vasten hän voi peilata omia ajatuksiaan ja jonka kanssa yhteistyössä hän voi omaksua uusia tietoja, taitoja ja asenteita. Aikuisten vertaisoppimisen tutkimus on pitkälti keskittynyt muuan muassa työssäoppimiseen.
\end{abstract}

ELINIKÄISEN OPPIMISEN näkökulmasta vertaisoppiminen on hyvin mielenkiintoinen ilmiö, sillä sitä tapahtuu sekä arkioppimisessa että vapaan sivistystyön kaltaisissa non-formaaleissa ja koulun kaltaisissa formaaleissa oppimisympäristöissä. Kun vertaisoppimista ajatellaan tällä tavalla laaja-alaisesti, voidaan myös ajatella, että se laventaa luotettavina pidettävien tiedonlähteiden piiriä ja nostaa elinikäisen oppimisen hengessä epämuodollisemman oppimisen esiin.

Esimerkiksi vertaistukiryhmissä tapahtuvan oppimisen pohjalla oleva yksilön kokemustieto syvenee, kun sitä voi peilata ryhmän muiden jäsenten koke- muksiin ja toiminnan tukena usein käytettävään asiantuntijatietoon.

\section{PERINTEISTÄ VAPAAN SIVISTYSTYÖN OPISKELUA}

Vertaisoppimiselle on aiempaa vahvempi sosiaalinen tilaus. Siitä mainiona esimerkkinä toimii Kouluniminen vertaisoppimisen festivaali, joka käynnistyi vuonna 2012. Festivaalilla kuka tahansa sai ilmoittautua jakamaan jonkin hallitsemansa taidon eteenpäin. Myös kansalaisjärjestöissä on esimerkiksi vertaistukiryhmien suosion siivittämänä puhuttu enemmän vertaisuudesta. 
Suomen 11 opintokeskusta tukevat järjestöissä ja muuten aikuisopiskelijoiden keskuudessa tapahtuvaa omaehtoista vertaisoppimista opintokerhoissa. Opintokerho on perinteistä vapaan sivistystyön opiskelua, jossa vähintään viisi yli 15-vuotiasta aikuista voi perustaa ryhmän ja opiskella haluamaansa aihetta opintokeskuksen taloudellisen ja pedagogisen tuen avulla. Työnantajani OK-opintokeskus on halunnut korostaa opintokerhon vertaisoppimiseen liittyvää luonnetta nimeämällä ryhmät muutama vuosi sitten vertaisopintoryhmiksi. Kotisivullaan opintokeskus määrittelee vertaisopintoryhmän seuraavasti:

"Vertaisopintoryhmä sopii yhdessä oppimistavoitteensa ja aikataulunsa. Ryhmän jäsenet oppivat taitoja ja tietoja toinen toisiltaan. Opintoryhmätoiminta on ihanteellinen tapa lisätä yhteisöllisyyttä, jakaa osaamista, tutkia ja kokeilla uutta." (ok-opintokeskus.fi/node/56)

Tässä artikkelissa pohdin lyhyesti vertaisoppimista ja sen haasteita käytännön näkökulmasta järjestömuotoisessa aikuisoppimisessa. Perustan näkemykseni havainnoille, joita tein kymmenessä vertaisopintoryhmässä keväällä 2010 työtoverini koulutussuunnittelija Susanna Plathanin kanssa toimittamaamme Tietoa, taitoja ja hyvää filistä -nimistä vertaisoppimisen opasta varten. Tätä täydentävät aiemmin kirjoittamani raportti, jossa OK-opintokeskuksen tukemien opintokerhojen vetäjät arvioivat ryhmänsä toimintaa (Fields 2009) sekä vuonna 2012 laatimani selvitys opintokeskuksen jäsenjärjestöjen lähivuosien koulutus- ja osaamistarpeista. Pohdin tässä tekstissä muun muassa sitä, onko vertaisoppiminen mahdollista ja miten sitä voitaisiin opintokerhotoiminnassa edistää.

\section{VERTAISOPPIMISEN PARADOKSI OPINTOKERHOSSA}

Aikuiskasvatus-lehdessä 1/2009 Koskela pohti aidon vertaisuuden haastetta ja jopa mahdottomuutta opintokerhon kaltaisessa non-formaalissa opiskelumuodossa. Ryhmä nimeää itselleen vetäjän, joka usein myös toimii ryhmän ohjaajana. Tämä aiheuttaa vertaisuuden paradoksin: vaikka ryhmän ohjaaja ei olisikaan ammattipedagogi ja vaikka ohjausvastuusta usein ryhmissä kierrätetäänkin, suhde ohjattavan ja ohjaajan välillä on aina epäsymmetrinen, jossa toinen opastaa ja jakaa tietoa ja toinen vastaanottaa sitä. Tämä nakertaa Koskelan mielestä vertaisoppimisen yhteisen tiedonrakentelun pohjaa.

Samaan kysymykseen liittyy pohjoismaiseen opintokerhoperinteen demokratian ideaali (ks. esim. Salo 2008): opintokerhon tulee pystyä toimimaan demokraattisesti, mutta ilman johtamista harva ryhmä pystyy itse säätelemään toimintaansa niin, että esimerkiksi hiljaiset osallistujat saavat äänensä kuuluviin. Opintokerho siis tarvitsee fasilitaattorin tai muun vetäjän kyetäkseen demokraattiseen vertaisuuteen. Käytännössä tämä saattaa aiheuttaa hierarkkisuutta, mikä taas ei sovi käsitykseemme vertaisoppimisesta.

\section{RYHMIÄ LAIDASTA LAITAAN}

OK-opintokeskusta ylläpitävän sivistysjärjestön Opintotoiminnan Keskusliiton muodostaa 67 suomalaista kansalaisjärjestöä, joista useimpien jäsenyhdistyksissä toimii opintokeskuksen tukemia vertaisopintoryhmiä. Laaja kirjo kansanterveys- vammais- ja potilasjärjestöistä ympäristöjärjestöihin, kulttuurijärjestöihin ja pelastusalan järjestöihin takaa sen, että myös kerhojen kirjo on suuri. Kerhoja ovat esimerkiksi Suomen Punaisen Ristin osastojen ensiapuryhmät, vertaistukiryhmät sekä taide- ja liikuntaharrastusryhmät, joista osa on kuntouttavia. Noin kolme neljäsosaa ryhmistä on vapaaehtoisten vetämiä (Fields 2009). Esimerkiksi kuororyhmiä kuitenkin johtaa yleensä ryhmän ohjaajaksikin nimetty kuoronjohtaja.

Opintokerho tai vertaisopintoryhmä muistuttaa Wengerin (1998) käsitystä käytäntöyhteisöstä: niillä on kullakin muun muassa omat tavat opiskella, omat normit ja artefaktit, ja ne ovat syntyneet yhteisen intressin ympärille. Ryhmään liitytään joko elämäntilanteen tai harrastuksen tai jostain asiasta kiinnostumisen kautta, jolloin ryhmässä toimiminen ja ryhmään sosiaalistuminen edellyttää myös identiteetin rakentamista. Suurta osaa tutkimistani ryhmistä (Fields 2012a; 2009) pitää yllä jaettu käsitys oppimisen ilosta ja siitä seuraavasta "hyvän kierteestä": mitä 
hauskempaa ryhmässä on, sitä enemmän opitaan, ja mitä enemmän opitaan, sitä hauskempaa on.

\section{ONKO VERTAISUUS KÄYTÄNNÖSSÄ MAHDOTONTA?}

Havainnointia varten otin yhteyttä kahteentoista ryhmään, joista kymmenen toivotti minut tervetulleeksi. Havainnoimistani ryhmistä neljä oli taito- tai taideaineiden harrastusryhmiä, kolme vertaistukiryhmiä, kaksi terveyteen tai kuntoutumiseen liittyviä harrasteryhmiä ja yksi järjestötoiminnan osaamista kehittävä ryhmä. Ryhmien koko vaihteli havainnointihetkellä viisihenkisestä 24-henkiseen (ka. 12 opiskelijaa). Havainnoinnin lisäksi myös haastattelin kahdeksaa ryhmää saadakseni esiin oppijoiden näkökulman ja täydentääkseni havaintojani.

Havainnointi oli sekä strukturoitua että osittain laadullista. Sen tuloksista voi lukea tarkemmin vertaisoppimisen kirjaan laatimastani artikkelista (Fields 2012a). Tässä esitellään tulosten pääkohtia vertaisoppimisen valossa.

Strukturoitua havainnointia varten olin laatinut lomakkeen, johon olin koonnut teoreettisen kirjallisuuden ja kokemuksen perusteella erilaisia oppimistilanteita, joita opintoryhmissä yleensä esiintyy. Näiden esiintymistä havainnoin 15 minuutin aikajaksoissa. Laadullisesti kirjasin ylös erilaisia havaintoja sekä oppimisesta että ryhmien dynamiikasta. Tässä yhteydessä puhun jonkin verran eroista vetäjä- ja vertaisvetoisten ryhmien välillä.

Vertaisopintoryhmissä tapahtuvan oppimisen tutkimusta löysin työni tueksi varsin vähän, mutta havaintoni luokittelin osaksi Cockettin ja Makrosin (2008) havaintoihin perustuen seuraavaan neljään ryhmään:

- Ryhmätoiminnot (koko ryhmä tekee yhdessä jotain tai keskustelee opittavasta asiasta tai muusta asias-

ta) (371/1 011 havainnoitua tapahtumaa, 37\%)

- Osittaistoiminnot (osa ryhmästä tekee jotain keskenään, kysyy tai keskustelee opittavasta aiheesta tai muusta) (268/1011 havainnoitua tapahtuma, 26\%)

- Yksilötoiminnot (opiskelijat tekevät jotain yksin tai seuraavat videota tai muuta tallennetta) (51/1 011 havainnoitua tapahtumaa, $5 \%)$
- Ohjaajatoiminnot (ohjaaja puhuu, ohjaa, kysyy jne.) (321/1 011 havainnoitua tapahtumaa, 32 $\%)$

Ohjaajavetoisia oppimistapahtumia oli ryhmissä yllättävän runsaasti, noin kolmasosa, mikä todella haastaa käsityksen vertaisuudesta oppimisen perustana opintokerhoissa.

Ryhmien välillä oli kuitenkin eroja, jotka noudattivat tiettyjä jakoperusteita. Näissä käytin hyväkseni muun muassa Cockettin ja Makrosin havaintoja, ja jaoin ryhmät useammilla perusteilla kahteen porukkaan. Jakoperusteina olivat ryhmän koko (alle-yli kymmenen), kokoontumistila (pieni-suuri/ ulkona), tapaamisen kesto (alle-yli 90 min.) ja osallistujien ikä (nuoremmat-vanhemmat, jossa jako perustui havaintoihin ja haastatteluissa kerättyyn tietoon). Havainnoituja ryhmiä oli vähän, joten seuraavaksi esitellyt havainnot niiden eroista ovat viitteellisiä.

Eräs tärkeimmistä havainnoista koski ryhmien kokoa. Yleensä opintoryhmän tai muun pienryhmän kooksi suositellaan alle kahdeksaa henkeä (esim. Pennington 2005), mutta tässä aineistossa pienryhmissä ohjaajat olivat äänessä suurempia paljon enemmän (39 \% havainnoista). Suuremmat ryhmät taas jakautuivat usein luontevasti osaryhmiin, joissa osallistujat selittivät toisilleen tekemisen prosessia tai tekivät jotain yhdessä (33\% havainnoista). Pienryhmissä ohjaaja joutui erityisesti panostamaan siihen, että esimerkiksi hiljaisemmat ryhmäläiset saavat osallistua keskusteluun, kun taas pieniin osaryhmiin jakautuneessa porukassa tämä oli luontevampaa, eikä vaatinut erillistä johtamista tai fasilitointia.

Nostan tässä kohdassa osittaistoiminnot eli ne oppimistapahtumat, joissa osa ryhmästä tekee jotain yhdessä ja toiset jotain muuta, vertaisoppimisen kannalta tärkeään asemaan. Tämä siksi, että näissä tilanteissa kirjasin eniten yhteiseen tiedonrakenteluun liittyviä asioita: osallistujat kysyvät toisiltaan oppimiseen liittyviä kysymyksiä tai pohtivat yhdessä niiden ratkaisemista ilman ohjaajan välitöntä läsnäoloa. Myös vertaisvetoisiksi havaintojen ja haastattelujen perusteella mieltämissäni ryhmissä oli tällaisia toimintoja paljon enemmän kuin ohjaajavetoisissa. 
Tulkintani mukaan nämä toiminnot olivat ryhmissä lähimpänä vertaisoppimisen ideaalia, jolloin onkin tärkeää huomata, että vertaisoppimista tapahtuu suuressa ryhmässä usein tilanteissa, joissa opiskelijat ovat tasavertaisessa asemassa toisiinsa nähden ja raja ohjattavan ja ohjaajan väliltä hämärtyy tai katoaa. Oppijasta tulee havaintojeni mukaan enemmän kyselijä ja kyseenalaistaja, joka hakee toisilta vahvistusta oman ymmärryksen kehittämiseen, tai hänestä tulee yhteisen oppimisprosessin rakentaja.

Iän merkitykseen vertaisoppimisen käsittämisessä törmäsin jo aiemmin, kun kirjoitin raportin opintoryhmien vetäjien arvioista ryhmänsä toiminnasta ja oppimisesta (Fields 2009). Nuoremmat vetäjät nostivat vertaisuuden esille kuvailleessaan ryhmäänsä ja yhteistä opiskelua, mitä vanhemmat ryhmien vetäjät eivät tehneet lainkaan.

Sama havainto toistui tässä aineistossa sikäli, että ohjaajakeskeisissä vanhempien opiskelijoiden ryhmissä opiskelijat puhuivat ryhmän ohjaajasta kuten opettajasta eikä kuten vertaisesta puhutaan. Nuorempien osallistujien ohjaajavetoisissa ryhmissä tällaista puhetapaa ei esiintynyt. Muuten eroja ei ryhmien välillä iän suhteen suuresti ollut. Olen tulkinnut tämän heijastavan eri sukupolvien kokemuksia opiskelusta, joka kantaa myös epämuodollisempiin opiskeluympäristöihin. Vanhemmille opiskelijoille ohjaaja edustaa eräänlaista auktoriteettia, jota on hyvä kuunnella.

Eri-ikäiset ryhmäläiset vaikuttavat kuitenkin yhtä lailla tyytyväisiltä omaan ryhmäänsä, joten ainakaan vanhemman oppijan kokemukseen ryhmän hyvyydestä tai oppimisesta epäsymmetria ohjaajan ja ohjattavan välillä ei välttämättä vaikuta. Koska ryhmä muodostetaan vastaamaan opiskelijoiden omia tarpeita, tämä tulee myös hyväksyä.

Tapaamisten kestolla oli sen verran merkitystä, että lyhyissä alle puolitoistatuntisissa tapaamisessa korostui yhdessä tekeminen (53\% havainnoista) ja pidemmissä ryhmän hajoaminen osaryhmiin. Pienessä tilassa kokoontuvissa ryhmissä ohjaaja oli huomattavasti muita ryhmiä enemmän äänessä (43\% havainnoista), kun taas suuremmissa ryhmissä ja ulkona tehtiin asioita pienryhmissä, jolloin korostui yhteinen ongelmanratkaisu. Lisäksi koulumainen istumajärjestys tuotti koulumaista käytöstä. Monilla ryhmillä ei ole mahdollisuutta valita kokoontumistilaansa, mutta tämä havainto on siitä tärkeä, että ryhmä voi välillä tehdä asioita toisin, jos se haluaa vahvistaa vertaisuuden kokemusta: voidaan kokoontua ulkona, istua ringissä tai muuten eri tavoilla ja niin edespäin.

Ei ole ihme, että ohjaajavetoisiksi luokittelemissani ryhmissä ohjaaja määritteli pitkälti tapaamisen kulun. Osassa ohjaajavetoisissa ryhmissä kuitenkin ohjaaja vetäytyi välillä tietoisesti taka-alalle jättäen tilaa ryhmäläisten omalle ongelmanratkaisulle. Tämä kuitenkin vaatii sitä, että osallistujilla on omaa ennakkotietoa opiskeltavasta aiheesta. Havainnoimissani ryhmissä yhteinen keskustelu koski usein asioita, joista opiskelijoilla oli vahva yhteinen ymmärrys. Ohjaajavetoisissa ryhmissä ohjaajan taka-alalle jättäytyminen on tärkeää, koska niissä laadullisten havaintojeni mukaan ryhmäläiset olivat helposti passiivisempia myös ryhmän käytäntöjen suhteen ja heistä oli vaikeampi sanoa, mitä he tapaamisessa oppivat.

\section{VIRALLINEN JA EPÄVIRALLINEN VERTAISOPPIMINEN}

Jos havainnoimissani ryhmissä olikin yllättävän paljon ohjaajan otteessa tapahtuvaa toimintaa, niin ryhmän ympärille tuntuu syntyvän myös eräänlainen piilo-opetussuunnitelmallinen epävirallisen vertaisoppimisen piiri. Useassa ryhmässä opiskelijat kertoivat yhteisistä ponnistuksistaan esimerkiksi esiintymisten järjestämisessä, joiden yhteydessä he olivat oppineet toinen toiseltaan esimerkiksi organisoimista ja yhdessä toimimista. Ryhmän oppimistuloksen kannalta epävirallisesti opitut asiat eivät olleet aina oleellisia, mutta ne sitouttivat osallistujia ryhmään ja sen tavoitteisiin.

Tällaiset geneeriset taidot, kuten yhteistyökyky ja organisoiminen, syntyvät usein järjestötoiminnan "sivutuotteena", mutta ne ovat yhdistys- ja järjestötoiminnan ydintä: tällaista oppimista syntyy kaikenlaisessa vapaaehtoistoiminnassa riippumatta organisaation perustehtävästä ja aatteesta (Fields 2005). Ne 
tuntuivat tässä kontekstissa myös vahvistavan osallistujien yhteistä kokemusta yhteisön jäsenyydestä.

\section{KOHTI VERTAISOPPIMISTA}

Miksi opintokerhotoiminnan vertaisoppimisesta pitäisi olla kiinnostunut? Opintokeskuksissa jaetaan käsitys siitä, että laadukas oppiminen edellyttää, että kaikki ryhmän jäsenet osallistuvat tavoitteiden määrittelyyn ja kykyjensä mukaan toiminnan kehittämiseen (Opintokeskus Kansalaisfoorumi jne. 2004). Tämän takia on hyvä, että vertaisuutta vaalitaan ryhmissä, tapahtui se sitten yhteisen oppimistavoitteen tavoittelun tai" epävirallisen" vertaisuuden muodossa.

Eräs tapa edistää koko ryhmän osallisuutta on vetäjän kierrättäminen. Aiemmin (Fields 2009) olen havainnut, että mitä kauemmin ryhmän vetäjä vetää ryhmäänsä, sitä opettajamaisemmin hän arvioi käyttäytyvänsä esimerkiksi tavoitteiden asettelun suhteen. Havaintojeni perusteella myöskään "luontaista johtajaa” ei kannata valita kerhon ohjaajaksi, jos tavoitteena on vertaisoppiminen.

Pienissä ryhmissä vetäjän on tietoisesti kyettävä vetäytymään taustalle. Ohjaajasta tulee muuten liian dominoiva. Pienessä ryhmässä voidaan vertaisuutta edistää tekemällä tehtäviä esimerkiksi pareittain, suosimalla epäkoulumaista istumajärjestystä ja kierrättämällä ohjaajuutta. Pienryhmä tarvitsee ennemmin fasilitaattorin tai mentorin kuin johtajan. Kokoontumistila ja istumaratkaisut ovat myös ilmeinen tapa vähentää koulumaisuutta. Eräs tärkeimmistä havainnoistani on se, että ryhmä kannattaa välillä jopa tietoisesti jakaa pienempiin osaryhmiin, koska niissä vertaisten kesken tapahtuva tiedonrakentelu tuntuu toimiva parhaiten.

On totta, että vertaisopintoryhmän laatua pohditaan usein ryhmän kannalta, vaikka ryhmä sinällään ei voi oppia. Sen jäsenet oppivat, joskin voimakkaassa vuorovaikutuksessa keskenään (Koskela 2009). Järjestö- ja muuhun vapaaehtoistoimintaan kuuluu kuitenkin voimakas vastavuoroisuuden odotus: yksilöille tarjotaan mahdollisuuksia oppimiseen, että he antaisivat panoksensa yhdistyksen tai muun organisaation perustehtävän edistämiseen. Tällä tavalla järjestön kaltaisen vapaaehtoisorganisaation kyvykkyys sisältää myös vahvan kollektiivisen ulottuvuuden
(Fields 2005), ja opintoryhmät koetaan olennaiseksi osaksi toimivaa yhdistystä.

Vastavuoroisuuden oletukseen organisaatiossa vastataan parhaiten silloin, jos mukana oleva yksilö kokee olevansa aidosti osallinen. Aiemmin mainitsemani havainto kokemuksesta opintokerhon synnyttämästä hyvän kierteestä tukee osittain tällaista käsitystä.

\section{VERTAISOPPIMISEN PAIKKA}

\section{JÄRJESTÖTOIMINNAN TULEVAISUUDESSA}

Vuonna 2012 laatimani selvitys OK-opintokeskuksen jäsenjärjestöissä koetuista osaamistarpeista (Fields 2012b) sekä keskustelut jäsenjärjestöjen kanssa ovat vahvistaneet käsitystä siitä, että vertaisoppimisella on tulevaisuutta järjestötoiminnassa. Joissain yhdistyksissä sitä on käytetty ”sisäänheittotuotteena", jolla on saatu nuorempia vapaaehtoisia mukaan. Erityisesti epämuodollisemman vertaisoppimisen, kuten mentoroinnin ja ad hoc -tyyppisen jakamisen, kysyntä onkin muita suurempi järjestöissä, joissa koulutuksiin osallistuu nuoria (alle 25-vuotiaita) vapaaehtoisia.

Kokemukseni mukaan nuorten vapaaehtoisuutta määrittää muun muassa tarve epämuodollisuuteen ja tekemiseen asemien tavoittelun sijaan (ks. myös esim. Volbæk jne. 2003). Vertaisoppiminen jopa opintoryhmässä saattaa vastata tähän, joten yhdistysten uusiutumisen kannalta epämuodollisessa hengessä yhteisen tekemisen edistäminen on oleellista. Opintokerho tarjoaa tähän mahdollisuuden.

Olen aiemmin havainnut viitteitä siitä, että opintokerhon kaltainen pitkäkestoinen opiskelu tuottaa järjestötoiminnassa koettuja hyviä oppimistuloksia (Fields 2005). Vapaaehtoistoiminta on kuitenkin muuttunut lyhytkestoisemmaksi ja satunnaisemmaksi, jolloin ryhmään ei aina haluta sitoutua pitkäksi aikaa säännöllisesti. Tämä vaikuttaa myös siihen, miten nyt aloittavat ja tulevat vapaaehtoisten sukupolvet identifioituvat yhdistykseensä. Tämä identiteettityö, joka on tärkeä osa järjestötoiminnassa oppimista, vaatii yleensä hieman pidemmän ajan.

Tämä vaikuttaa myös tapoihin oppia järjestötoiminnassa, minkä seurauksena esimerkiksi pitkäkestoisten kurssien suosio osoittaa hiljaista hiipumista 
(Fields 2012b). "Uusien” vapaaehtoisten oppimisprosesseista tiedetään vielä varsin vähän.

Mitä vertaisuuden paradoksiin tulee, on selvää, että opintokerhoissa vertaisoppimista ei voi esiintyä puhtaasti kaiken aikaa kaikenlaisissa ryhmissä. Joka tapauksessa jopa kaikkein ohjaajakeskeisimmässä ryhmässä havainnoin runsaasti toimintaa, joka oli koko ryhmän tai osan ryhmästä alkuun saattamia ja joissa opiskelijat olivat aktiivisia vertaisia toisilleen. Yhdistyksissä toimivia opintoryhmiä ja muita käytäntöyhteisöjä kannattaa ohjata käyttämään monenlaisia, myös epämuodollisia vertaisoppimisen menetelmiä, ei vain opintoryhmiä. Vertaisoppimisen kautta voitaisiinkin löytää keinoja mahdollistaa yhdistystoiminnassa tarvittava osaaminen ja samalla yhteisöllisyys muiden vapaaehtoisten kanssa, joka saattaa jäädä hämäräksi jos toiminta on koko ajan satunnaisempaa. Opintokerhonkin avulla tätä voidaan tehdä, mikäli kerhot pystyvät hallinnollisista velvoitteistaan huolimatta luomaan epämuodollisen tunnelman. Järjestömuotoisen vertaisoppimisen vieminen esimerkiksi sosiaaliseen mediaan voi edistää tätä tarkoitusta myös.

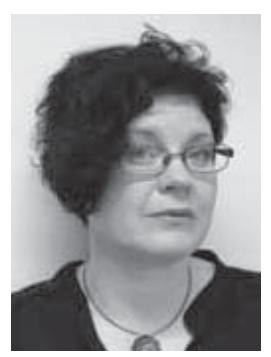

Marion Fields

VTT

suunnittelija

OK-opintokeskus

\section{LÄHTEET.}

Cockett, L. S \& Makros, H. B. (2008) Space use and the organization of participation in peer-supported learning. Esitelmä, IADIS International Conference on Cognition and Exploratory Learning in Digital Age (Celda 2008). http://www.iadis.net/dl/final_ uploads/200818C038.pdf (viitattu 31.3.2011).

Fields, M. (2012a) Havaintoja vertaisoppimisen organisoinnista. Esimerkkejä OK-opintokeskuksen jäsenjärjestöjen vertaisopintoryhmistä. Teoksessa M. Fields ja S. Plathan (toim.) Tietoa, taitoja ja hyvää fiilistä - vertaisoppimisen taustaa ja kokemuksia järjestötoiminnassa. Helsinki: Opintotoiminnan Keskusliitto ry.

Fields, M. (2012b) Vapaaehtoistoimintaa, viestintää ja verkostoitumista. Katse OK-opintokeskuksen jäsenjärjestöjen lähitulevaisuuden koulutus- ja osaamistarpeisiin. Helsinki: OK-opintokeskus. $\leftarrow$ http://www.ok-opintokeskus.fi/sites/default/files/ Koulutustarvekysely\%202012\%20artikkeli.pdf $\rightarrow$ (viitattu 8.4.2012)Fields, M. (2009) Oppiminen ja vertaisten tapaaminen on iloinen tapahtuma. OKopintokeskuksen piirissä vuonna 2008 toimineiden opintokerhojen ohjaajien arvioita omansa ja kerhonsa toiminnasta. Helsinki: OK-opintokeskus.

Fields, M. (2005) To Educate, Empower or Economise? Lifelong learning in civil society organisations.

Turku: Koulutussosiologian tutkimuskeskus, TY.
Koskela, J. (2009) Opintokerho pedagogisena toimintana. "Oppivan vertaisryhmän" kehittämisen problematiikkaa. Aikuiskasvatus 2009: 1, 58-63.

Opintokeskus Kansalaisfoorumi; Kristillinen opintokeskus, TJS Opintokeskus \& Vihreä Sivistys- ja Opintokeskus ViSiO (2004) JÄLKI. Järjestökoulutuksen laatukäsikirja. Helsinki. Saatavilla verkosta: http://www.tjsopintokeskus. fi/easydata/customers/opintokeskus/files/pdf_. tiedostot/JALKI.pdf (ladattu 04.08.2010).

Pennington, D. C. (2005) Pienryhmän sosiaalipsykologia. Helsinki: Gaudeamus.

Topping, K. J. (2005) Trends in Peer Learning. Educational Psychology 25:6, 631-645.

Volbæk, D. \& Selle, P. (2003) Generations and Organizational Change. Teoksessa: P. Dekker \& L. Halman (eds.) The values of Volunteering. Crosscultural Perspectives. New York: Kluwer, 161-178.

Wenger, E. (1998) Communities of practice. Learning, meaning, and identity. Cambridge, UK: Cambridge University Press. 